\title{
THE TROUBLED DISTINCTION BETWEEN CAPITAL GAIN AND ORDINARY INCOME
}

\section{Introduction: The Capital Gain-Ordinary Income Distinction}

The Internal Revenue Code divides taxable gains and deductible losses into two classes - ordinary and capital - and prescribes different tax treatment for each. ${ }^{1}$ Broadly speaking, capital gains are taxed at preferential, lower rates. ${ }^{2}$ Ordinary losses, if deductible, may be deducted from any taxable income ${ }^{3}$ but only in certain circumstances may the loss be carried forward. ${ }^{4}$ Capital losses are deductible from only a limited segment of income ${ }^{5}$ but may be carried forward indefinitely. ${ }^{6}$ The favorable consequences of capital gain taxation and the mixed consequences of capital loss treatment motivate taxpayers to seek "capital" or "ordinary" treatment as their interests in particular cases dictate. ${ }^{7}$ The Treasury's interest in maximizing revenue conflicts with the taxpayers' desire to minimize taxes, and thus encourages the government to oppose the taxpayers' efforts. The resulting controversy has placed much pressure on the "capital"- "ordinary" dichotomy.

The Code effects the division between capital and ordinary gain or loss by prescribing "capital" treatment for the gains and losses arising on the "sale or exchange" of "capital assets," which are described as a limited class of property: $:^{3}$ it thus requires a particular kind of transaction in a particular type of property to qualify for capital treatment. The "sale or exchange" requirement ${ }^{10}$ can be interpreted in relation to sections 1001 , which outlines the method of computing gain or loss on the "sale or other disposition of property," and 61(a)(3), which brings "gains derived from dealings in property" into gross income. ${ }^{11}$ These provisions apply only to transactions which "close out" the taxpayer's ownership interest in the property involved.12 Capital assets is defined as "property held by the taxpayer" which does not fit within five exclusionary categories. ${ }^{13} \mathrm{By}$ and large, the exclusionary cate-

1. See INT. Rev. Cone of 1954, §§ 1, 61, 165, 1201, 1202, 1211.

2. INr. REv. CODE OF 1954, § 1201.

3. INT. REv. CODE OF 1954, §§ 63(a), 165.

4. INT. REv. CoDE of 1954, § 172.

5. INT. Rev. CoDE of 1954, § 1211.

6. INT. REv. Code of 1954, $\S 1212$, as amended, Pub. L. No. 88-272, 88th Cong., 2d Sess. § 230 (Feb. 26, 1964).

7. Compare Grier v. United States, 120 F. Supp. 395 (D. Conn. 1954), aff'd per curian 218 F.2d 603 (2d Cir. 1955) with Leland Hazard, 7 T.C. 372 (1946).

8. INT. Rev. Code of 1954, § 1222.

9. INT. REv. CoDE OF 1954, § 1221.

10. INT. REv. CODE of 1954, § 1222.

11. See Bittrer, Federal Income, Estate and Gift Taxation 366-67 (2d ed. 1958).

12. Cf. Bittker, Sales and Other Dispositions of Property 51 (unpublished materials in Yale Law Library, 1963).

13. INT. Rev. CoDE of 1954, § 1221. 
gories produce ordinary tax treatment for the proceeds of ordinary business dealings in property and leave capital treatment for proceeds from other property dealings. ${ }^{14}$ These exclusionary subsections ${ }^{15}$ describe property whose disposition generates income in the course of the taxpayer's common vocational activities, such as property held for sale to customers ${ }^{16}$ and accounts receivable acquired for services rendered. ${ }^{17}$ One of the exclusionary provisions, section 1221(2), excepts from capital asset treatment real and depreciable personal property used in the taxpayer's business, even though such property is devoted to rather than customarily dealt in by the taxpayer's business. Section 1221(2) property, however, may still generate capital gain treatment through the special provisions of section $1231 .^{18}$

The particular method the statute uses to delimit the class of transactions receiving capital treatment seems to jeopardize the very distinction it attempts to create. By the terms of the statute, all property held is entitled to capital asset treatment unless explicitly excluded. ${ }^{10}$ Given the broad and flexible concept "property" has become in the general body of law, ${ }^{20}$ taxpayers will often be able to fashion income-producing activity into dispositions of "property." For example, the compensation for an entertainer's product endorsements might take the form of a sale of his right to privacy rather than payment for services $;^{21}$ and the gain potential existing in a favorable requirements contract could be realized through sale of the contract rights rather than through profits generated by performance of the contract.22 This ability to shape transactions may well enable the taxpayer to avoid the application of the exclusionary clauses. ${ }^{23}$ Had courts taken the position that the exclusionary categories provided the only exceptions to a broad warrant for the capital gain or loss treatment of property sales and exchanges, the class of transactions receiving capital treatment might have absorbed a substantial segment of all income-producing activities. To prevent such an erosion of

14. See Surrey, Definitional Problems in Capital Gain Taxation, 69 HARv. L. Rev. 985, 989-96 (1956), and text at notes 125-55 infra.

15. INT. Rev. CODE OF 1954, § 1221 (1)-(5).

16. INT. REv. CODE of 1954, $\$ 1221$ (1).

17. Int. Rev. Code of 1954, $\$ 1221$ (4).

18. Victory Housing No. 2, Inc. v. Commissioner, 205 F.2d 371 (10th Cir. 1953). Compare Rollingwood Corp. v. Commissioner, 190 F.2d 263 (9th Cir. 1951).

19. INT. Rev. Code of 1954, \$1221.

20. See, e.g., United States v. Causby, 328 U.S. 256 (1946) ; Pittsburgh Athletic Co. v. KQV Broadcasting Co., 24 F. Supp. 490 (W.D. Pa. 1938).

21. See Feinberg, Recent Developments in the Laze of Privacy, 48 Colunr. L. Rev. 713 (1948) ; Warren \& Brandeis, The Right to Privacy, 4 Harv. L. Rev. 193 (1890). See also Miller v. Commissioner, 299 F.2d 706 (2d Cir. 1962) ; Runyon v. United States, 281 F.2d 590 (5th Cir. 1960).

22. See Commissioner v. Pittston Co., 252 F.2d 344 (2d Cir. 1958).

23. For example, the right to issue endorsements on all products might be sold to a servicing company, thereby avoiding a pattern of sales which might bring section 1221 (1) into play. Cf. Mauldin v. Commissioner, 195 F.2d 714 (10th Cir. 1952). 
the ordinary income base, courts have felt a need to go further than the exclusions in narrowing the range of capital gain treatment. ${ }^{24}$

Judicial pursuit of the distinction between capital gain and ordinary income has taken courts beyond the obvious cases where transactions not specifically denied capital gain treatment so resemble dealings giving rise to ordinary income that differentiation would be unseemly. ${ }^{25}$ It is the court's search for standards in the penumbral area, where the proceeds from property transactions may be refused capital gain treatment although not clearly denied such treatment by the import of the statutory language, which is the subject of this Comment. Though some courts have limited the class of privileged transactions by finding no sale or disposition, ${ }^{26}$ an absence of "property," or an exclusionary category satisfied, ${ }^{28}$ this Comment is limited to judicial performance in situations acknowledged by the courts to involve a sale or other disposition of non-excluded property.

Here for thirty years courts have sought in the statute, and in the economics of transactions, satisfactory standards for guiding their decisions. Their failure is evidenced by the atmosphere of uncertainty and confusion which pervades this shadow area. ${ }^{29}$ An examination of the operative policies and the state of the law may lead some to reject the statutory distinction, perhaps concluding that the arguments for a special tax category are unconvincing ${ }^{30}$ or that a comprehensive revision of the statutory scheme is essential. ${ }^{31}$ But the political climate indicates that such major changes are not imminent $;^{32}$ and, since courts must decide cases, the search for standards must continue.

\section{The Policies Underlying The Distinction}

In interpreting the broad wording of the statute, it is only natural that courts have looked for standards to policies commonly understood to support the capital gain-ordinary income distinction. Three major policies - ameliorating the effect of telescoped income, encouraging investment, and increasing

24. See Corn Products Refining Co. v. Commissioner, 350 U.S. 46, 51-54 (1955).

25. Compare Charles E. McCartney, 12 T.C. 320 (1949) with Commissioner v. P. G. Lake, Inc., 356 U.S. 260 (1958).

26. See, e.g., Rohmer v. Commissioner, 153 F.2d 61 (2d Cir. 1946). See also Duke, Foreign Authors, Inventors, and the Income Tax, 72 YALE L. J. 1093, 1100-16 (1963); Fulda, Copyright Assignments and the Capital Gains Tax, 58 YaLE L. J. 245 (1949).

27. See, e.g., Miller v. Commissioner, 299 F.2d 706 (2d Cir. 1962).

28. See, c.g., Hollis v. United States, 121 F. Supp. 191 (N.D. Ohio 1954).

29. See generally, Surrey, Definitional Problems in Capital Gain Taxation, 69 HARv.

L. REv. 985 (1956).

30. See Clark, The Paradox of Capital Gains: Taxable Incone That Onght Not to be Currently Taxed, in 2 House Comm. on Ways \& MEANs, TaX Revision Compendrum 1243 (Comm. Print 1959).

31. Note, Distinguishing Ordinary Income From Capital Gain Where Rights to Future Income Are Sold, 69 HARv. L. Rev. 737, 748 (1956).

32. See Presidential Message on Tax Reduction and Reform, 109 Cong. Rec. 919, 926-27 (daily ed. January 24, 1963), and compare H.R. 8363, 88th Cong., 2d Sess. § 219 (1963). 
the liquidity of investment funds - are often invoked in support of decisions. On examination, each of these policies seems at best only partially reflected in the statutory provisions. Consequently, no single policy provides a successful test for distinguishing capital gain from ordinary income transactions. ${ }^{33}$

\section{Telescoping}

Since increases in the value of investments often accrue during a period of years, it is considered unfair to tax an accumulated gain in the year of realization at a rate substantially higher than the rate which would have prevailed had the gain been recognized as it accumulated. ${ }^{34}$ Originally, the policy of ameliorating the effect of progressive taxation on telescoped income was reflected in a provision which qualified for capital treatment only capital assets held for two years or longer. ${ }^{35}$ A 1942 amendment ${ }^{36}$ reduced the minimum holding period to six months, thus increasing the number of situations not involving telescoping in which capital gain treatment can be obtained. Although this amendment rebuts an inference that the absence of telescoping is an affirmative reason for denying capital gain treatment, it does not perforce nullify totally the operative effect of the telescoping policy. ${ }^{37}$ The policy remains applicable to all transactions involving gain accumulated over more than one tax period. And while invocation of this policy conventionally involves reference to gains accumulated in the past, the rationale seems equally in point when a taxpayer in the year of sale receives proceeds which represent the profits he could expect to earn himself by holding and using the property sold. ${ }^{38}$

The telescoping policy is most persuasive as applied to the investor who in one sale realizes the gradually accumulated gain on a long time, major investment. ${ }^{39}$ Assuming relative stability in his other income, progressive taxation would enlarge his tax burden. ${ }^{40}$ But consider the diversified investor who each year realizes the gain on a portion of a substantial investment port-

33. See text accompanying notes 51-59 infra.

34. H.R. Rep. No. 350, 67th Cong., 1st Sess. 10 (1921) ; Seltzer, The Nature and Tax Treatment of Capital Gatns and Losses 83-86 (1951).

35. Int. Rev. Code of 1939, § 117 (a) and (b), 53 Stat. 50 (1939).

36. Revenue Act of 1942, $\S 150$ (a) and (b), 56 Stat. 843 (1942). See INT. REv. CODE of 1954, § 1222.

37. But see Clark, op. cit. supra note 30, at 1244-45; Miller, Capital Gains Taxation of the Fruits of Personal Effort: Before and Under the 1954 Code, 64 Yale L.J. 1, 10 (1954) ; Note, 69 Harv. L. Rev. 737, 739-41 (1956).

38. See ALI, Draft of A Study of Definitional Problems in Capital Gains TAXATION 84-85 (1960).

39. Even for the long-term, single-asset investor, the effect of telescoping is not so harsh as it may first appear. The owner of appreciated property receives the benefit of the productive power of the untaxed accretions to value prior to realization. This benefit - the use of an amount which would have been payable as tax had the accretion been taxable when it accrued - may be valued at the compound interest such amount would earn during the years between accrual and realization.

40. See INT. REv. CoDE of 1954, §§ 1301-04, for other statutory devices designed to counteract the effect of telescoping income. 
folio, and the investor who experiences within a short time a substantial increase in the value of an investment, regardless of the length of time the investment had been carried. These people are the beneficiaries of the capital gain provisions, although it cannot be said that applying the ordinary graduated tax to their income would be prejudicial because of any bunching effect. Similarly, corporations, which are affected only slightly by the impact of a graduated tax, 41 do not require a downward adjustment of tax to accommodate telescoping; nor does the person who, through such means as installment sales, ${ }^{42}$ spreads the income from his transactions over many years.

The capital loss carry-over provisions ${ }^{43}$ reflect a different aspect of the telescoping problem. By limiting the deductibility of capital losses to offsetting capital gain and $\$ 1000$ of ordinary income in any year, ${ }^{44}$ the statute reflects a general feeling that the advantages of capital gain treatment should be balanced by restricting the capital loss deductions. However, while capital loss and gain, if realized in the year accrued, might fairly reflect income if offset in this manner, capital loss like capital gain may be bunched into one tax period. Recognizing that the capital gain realized during one tax period may be insufficient to offset a telescoped loss, the Code provides that capital losses may be carried forward until fully deducted. ${ }^{45}$

\section{Investunent Encouragement}

A second policy justification for providing preferential tax treatment is the stimulating effect lower tax rates have on investment and, hence, on economic growth. ${ }^{40}$ Investment, both financial and real, involves risking economic resources currently exchangeable for consumption goods and services, in the expectation of receiving a greater amount of economic resources in future periods. As taxes reduce the claims on goods and services an investor may expect to control in future periods, they similarly reduce the attractiveness of risk-taking opportunities. Lowering the tax rates on the rewards of investment encourages investment, since the additional amount of after-tax income will bring more risk situations within the investor's margin of willingness to forego present consumption. The long-run effect of lower tax rates on investment income would be a shift from consumption to savings, with a resulting increase in investment and economic growth.

41. INT. Rev. Code of 1954, § 11.

42. The effect of telescoping on installment sales varies depending upon the relationship of the payment arrangements to the manner in which appreciation in value would accrue.

43. Int. Rev. Code of 1954, § 1212 .

44. Int. Rev. Code of 1954, § 1211(b). Corporations do not even enjoy the privilege of using the $\$ 1000$ ordinary income offset. See INT. REv. CodE of 1954, $\$ 1211$ (a).

45. Int. Rev. Code of 1954, § 1212, as amended, Pub. L. No. 88-272, 88th Cong., $2 d$ Sess. \$ 230 (Feb. 26, 1964).

46. See Presidential Message on Tax Reduction and Reform, 109 Cong. Rec. 919, 926 (daily ed. January 24, 1963) ; and see generally ButTers, Thompson \& Bollinger, EfFects of Taxation: INVEstarent BY INDIVIDUals (1953). 
In effectuating the policy of encouraging investment, the statute operates in a selective manner, bestowing the preferential treatment only on certain forms of investment gain. An investment may offer a regular, recurring payout, a residuary profit realizable only through the disposition of the investment property, or a return mixing these two types of gain. The capital gain provisions apply only to the residuary profits; therefore, equity investments, which channel gains into accretions in property value, are the principal beneficiaries of capital gain treatment. When gains are channeled into accretions in property value, rather than paid out periodically, a reinvestment occurs which contributes to the continued growth of capital. The effect of the statutory policy is, thus, to favor reinvestment of enterprise profits and initial investment in opportunities which offer the prospect of reinvestment. Windfalls, however, manifest themselves in the same form as reinvested profits. Although windfalls do not fit within the policy of encouraging investment by shielding anticipated gains from high tax rates, the statutory technique of favoring accrued gains has the effect of rewarding them.

\section{Investment Fund Mobility}

The third policy frequently invoked in support of the capital gain provision is the increased mobility accorded investment funds by lower tax rates, and the beneficial effect such mobility has on the production of tax revenue. ${ }^{47}$ An investor considering a change in the allocation of his investment capital must weigh the productive power of a profitable current investment against the productivity of an amount equal to the value of the current investment reduced by the tax payable on the appreciation in value and then invested in another enterprise. As the tax rate decreases and threatens to absorb a smaller proportion of the accrued gain on an investment, the investor becomes more willing to cash in his appreciated investment property to take advantage of new investment opportunities. The rate of return required in order for the new investment of the reduced amount to equal the yield of the old investment becomes lower, and the investment opportunities offering such a return, more plentiful.

When the lock-in effect of taxes substantially affects decisions about the disposition of assets, the market allocation of resources will become inefficient. The theory of market efficiency postulates that each individual will allocate his investment resources to maximize their yield. Because individuals have varying aspirations and abilities, different people may value the same investment opportunity differently, but each can be expected to invest in those opportunities which appear most valuable to him. In obtaining property he thinks has the greatest relative value, the individual maximizes the deployment of his investment capital. When the whole community acts in this manner, resources are allocated with maximum market efficiency. If the amount

47. See H.R. Rep. No. 2333, 77th Cong., 1st Sess. (1942), reprinted in 1942-2 CuMr. BuLL. 372, 396. 
of taxes payable on a taxable disposition of property controls investors' decisions not to shift from one investment asset to another, maximum efficiency will not be obtained.

Investment immobility induced by tax considerations retards the collection of government revenue. ${ }^{48}$ The production of government revenue through the taxation of accrued investment gains depends upon the owner's disposing of his property in a taxable transaction. As any tax rate discourages sales and other taxable transfers of property in proportion to its severity, a reduced rate may well result in greater revenue production. The Code's provision that heirs take appreciated property at a stepped-up basis, without assessing an income tax on the capital accretion, ${ }^{49}$ accentuates the discouragement of transfers ordinarily induced by high tax rates; the postponement of realization until the owner's death will exhaust, the potential for government revenue in the appreciation of property. While the preferential tax rates reduce the "lock-in" effect of taxes and thereby hasten the occurrence of taxable events that may be postponed, the capital gain provisions also apply when a taxpayer must dispose of his property - upon the retirement of a bond, ${ }^{50}$ for example. They likewise apply to the installment payments under a sale agreement which provides for periodic payments roughly equivalent to the income produced periodically by the transferred property.

\section{The Single Policy Approach}

While these policies supplement the bare words of the statute in suggesting the direction the capital gain provisions should take, they do not provide ready tests for determining the applicability of capital treatment. The policies would apply to a range of transactions both included and excluded from the preferential capital treatment, and the statute, in turn, applies to situations that fall both within and without the range of each policy's grasp. ${ }^{51}$ If the statute is an inaccurate expression of each policy, it would seem unreasonable to use any one of the policies alone as the tool for distinguishing ordinary income from capital gain transactions. There is no apparent basis for a belief that any particular policy represents the legislative purpose; the motivating force behind the capital gain provisions seems to be an amalgam of the stated policies. ${ }^{62}$ Dividend income, although part of investment return, is not granted capital gain treatment, possibly out of deference to the telescoping policy;

48. See Burnet v. Harmel, 287 U.S. 103, 106 (1932).

49 INT. REv. CoDE of 1954, §§ 102, 1014.

50. INT. REv. CODE OF 1954, \& 1232(a) (1).

51. See, e.g., text accompanying notes $39-42$ and note 46 supra.

52. Each of the three policies has been invoked in support of the capital gain provisions by the House Ways and Means Committee. See H.R. REP. No. 350, 67th Cong., 1st Sess. 10 (1921) ; H.R. REp. No. 2333, 77th Cong., 1st Sess. (1942), reprinted in 1942-2 Cum. Butz. 372, 396-97. Although there appears to be no explicit congressional recognition of the policies' interaction, the failure of Congress to reflect fully one policy in the Code, coupled with periodic references to each of the policies, leads one to the conclusion that the "statutory policy" is an amalgam. 
and installment sales proceeds, though they may fail to invoke the telescoping and fund liquidity policies, are treated as capital gain, perhaps out of respect for the investment policy.

On occasion, however, courts have fashioned their opinions from the fabric of a single policy. In Commissioner v. Gillette Motor Transport, Inc., ${ }^{63}$ the Supreme Court was asked to decide the tax treatment to be accorded a sum received by a common carrier from the government in compensation for a "temporary taking" of its business facilities for ten months during the Second World War. ${ }^{54}$ One of the reasons assigned by the Court for denying capital gain treatment was the failure of the transferred property to qualify within the Congressional purpose.

This Court has long held that the term "capital asset" is to be construed narrowly in accordance with the purpose of Congress to afford capital gain treatment only in situations typically involving the realization of appreciation in value accrued over a substantial period of time, and thus to ameliorate the hardship of taxation of the entire gain in one year. ${ }^{55}$

The Court's approach points up some of the difficulties raised by direct resort to a single policy. Such a simplistic description of policy may avoid the diffculties of relating competing policies and statutory provisions into a coherent body, but it likewise prevents the standard against which transactions are judged from reffecting a complete policy picture. The Court, for instance, fails to reconcile the provision for a six months holding period with its "appreciation in value accrued over a substantial period of time" requirement. The six month holding provision indicates that the absence of telescoping has no effect in reaching a decision against the grant of capital gain treatment. ${ }^{50}$ Concentration on any one of the policies, even when correctly interpreted, can produce a gross distortion in the projected range of property embraced by "capital asset."

Thus, the individual policies underlying the capital gain provisions, though regularly invoked by judicial opinion-writers, are but dim lanterns in the twilight segment of capital gain law. Whether or not expert economists could divine and then apply the accommodation reached among the various policies, it seems clear that courts, which have not even attempted the task, are not competent to do ${ }^{50} .^{57}$ Unable to find standards capable of supporting reasoned

53. 364 U.S. 130 (1960).

54. Id. at 131 .

55. Id. at 134 .

56. See text accompanying notes $35-37$ supra.

57. See the concurring opinion in United States v. Dresser Industries, Inc., $12 \mathrm{Am}$. Fed. Tax R. 2d 5895, 5899, (5th Cir. 1963), in which Judge Brown calls the substitute for ordinary income doctrine "both bad economics and faulty law:"

Tax law, by the hand of man, the Acts of Congress, and the doubtful clarification by Judges is complex enough without making it more so through the importation of bad economics. For before we realize it, economics, which knows no law of stare decisis, is infected by poor or bad law to set in train tax consequences because of what Courts have said, not because of what the actualities really are. 
elaboration, ${ }^{58}$ courts have explained their decisions in terms of technical distinctions. These distinctions fall into three categories. The doctrines in two of these categories center on the statutory requirements: does the transaction constitute a "sale or exchange" or other taxable disposition; and does it involve "property" embraced by the Code as a capital asset? The doctrine in the third category explores the relationship between capital gain and income which is taxed at ordinary rates: are the proceeds from a sale or exchange a substitute for ordinary income? In historical terms, the courts tended to emphasize first "sale or exchange," then "substitute for ordinary income," and, most recently, the definition of "property."

\section{The Sale or Exchange Doctrine}

The capital gain-ordinary income distinction has engendered a body of case law concerning the scope of the "sale or exchange" requirement that section 1222 imposes for capital gain treatment. Section 1001 uses the phrase sale or other disposition in specifying appropriate occasions for computing gain or loss on property transactions, and this phrase is evidently read into section 61 (a) (3), which taxes "gains derived from dealings in property," and section 165, which allows deductions for losses "sustained during the taxable year." that sale or exchange was employed in the Code to denote a narrower range of transactions than sale or other disposition. Within section 1001, the phrase sale or exchange is used in the subsection treating recognition of the computed gain or loss without either indicating that sale or exchange has a narrower scope than sale or other disposition or raising the implication that recognition on dispositions other than sales or exchanges might be governed by other rules. ${ }^{61}$ Furthermore, legislative history discredits the theory that sale or exchange conveys a more restricted meaning. The House Ways and Means Committee Report on the 1921 Revenue Act stated that the capital gain provisions, which used the words sale or exchange, were to apply upon "the sale or other disposition of capital assets. . . ."62

Nonetheless, courts soon found sale or exchange to encompass a smaller group of transactions than sale or other disposition. True, in early cases, the Board of Tax Appeals adopted the position that sale or exchange was as broad as sale or other disposition. ${ }^{63}$ But it soon reversed its stand, overruling an earlier holding that the retirement of a bond upon maturity con-

58. See Hart \& Sacks, The Legal Process: Basic Problems in the Making and Application of Law 160-79 (tentative ed. 1958).

59. See Fairbanks v. United States, 306 U.S. 436 (1939); Hort v. Commissioner, 333 U.S. 28 (1941) ; and Corn Products Refining Co. v. Commissioner, 350 U.S. 46 (1955).

60. See Bittrer, Federal Incone, Estate and Gift Taxation 366-67 (2d ed. 1958). But see Herbert's Estate v. Commissioner, 139 F.2d 756 (3rd Cir. 1943) (dictum) and Treas. Reg. § 1.1001-1(c) (1957).

61. See Bittker, Federal Income, Estate and Gift Taxation 392 (2d ed. 1958 ).

62. H.R. REP. No. 350, 67th Cong., 1st Sess. 10-11 (1921).

63. See Henry P. Werner, 15 B.T.A. 482, 484 (1929). 
stituted a "sale or exchange" of the bond for purposes of the capital gain provisions. ${ }^{64}$ Invoking the "plain meaning" rule ${ }^{65}$ of statutory construction, the Board said:

It is elemental that where a statute is clear and unambiguous in its terms and provisions resort should not be had to legislative history to determine the limits of its compass. The statute in question is so simple in construction and so clear in meaning that it justifies no resort to the Congressional Committee's reports as an aid in the interpretation thereof.

The words "sale or exchange" are ordinary words of well established meaning. Taken in their context they are susceptible of no misconstruction. Payment of the amounts specified in the bonds, either at maturity or pursuant to an authorized call prior to maturity, is not a "sale or exchange" of such bonds. It is merely the payment of an obligation according to its fixed terms. ${ }^{e 6}$

This approach received the endorsement of the Supreme Court in a case also involving the redemption of a bond before maturity: Mr. Justice McReynolds, citing the Board decision with approval, announced, "Payment and discharge of a bond is neither sale nor exchange within the commonly accepted meaning of the words," or, perforce, within the meaning of the statute. ${ }^{67}$

The "sale or exchange" doctrine has shown much flexibility. The effect of the doctrine on particular fact situations depends on two operations the definition of sale or exchange and the application of the selected definition. Those courts which find a "sale or exchange" missing usually subscribe to a definition of sale as a transaction in which one party acquires a property interest in the thing sold and the other for a valuable consideration parts with that interest ${ }^{68}$ an exchange is a transaction in which each party

64. John H. Watson, 27 B.T.A. 463 (1932).

65. See Wellington \& Albert, Statutory Interpretation and the Political Process: $A$ Comment on Sinclair v. Atkinson, 72 Yale L.J. 1547, 1549-50 (1963) ; HarT \& Sacks, The Legal. Process: Basic Problems in the Making and Application of Law 1145, 1267-69 (tentative ed. 1958).

66. John H. Watson, 27 B.T.A. 463, 465 (1932).

67. Fairbanks v. United States, 306 U.S. 436, 437 (1939). The fact that bonds are involved in the transactions considered in these cases may provide an explanation of their result. The gain made on redemption of a bond purchased at a discount may be considered deferred interest, and interest is normally taxed at ordinary rates. See INT. Rev. CoDE of 1954, § 61 (a) (4) ; cf. Hort v. Commissioner, 313 U.S. 28 (1941). Congressional reaction to the judicial treatment of bond redemption is instructive: in 1934 redemption of a bond was stipulated to be an exchange, Revenue Act of 1934, ch. 277, \$ 117 (f), 48 Stat. 715 [now INT. Rev. Code of 1954, \$ 1232(a)(2)] and the 1954 Code rendered the gain received on the sale or exchange of bonds ordinary income to the extent the gain could be attributed to original discount, INT. REv. Code of 1954, § 1232 (a) (2) (A) (i), presumably because of its close relation to interest. Thus, there seems to have been some recognition of the vacuity of the sale or exchange-sale or other disposition distinction. Whether or not the peculiar nature of bond transactions suffices to explain the courts' first use of a restrictive definition of sale or exchange, the result, once reached, was applied more generally.

68. See, e.g., Charles E. McCartney, 12 T.C. 320, 324 (1949). 
parts with a property interest the other then acquires. ${ }^{69}$ The crucial question under this definition is whether a property interest passed between the two parties or simply was extinguished and vanished. For the interest to pass there must be an identity between the property right the transferor had and the one the transferee receives. ${ }^{70}$ Some courts have demonstrated remarkable ingenuity in tracing rights from one party to another in order to find a sale or exchange, while other courts have displayed a comparable lack of ingenuity in pursuing the same task with, of course, different results. ${ }^{71}$ There is, however, nothing inevitable about the preceding definitions, and other courts have adopted a more simply applied and easily satisfied definition.

A group of cases involving the termination of exclusive agency or franchise contracts illustrates the various ways in which courts work with the concept of sale or exchange. Commissioner $v$. Starr Bros. ${ }^{72}$ deals with the termination of the exclusiveness of a druggist's exclusive right to sell a manufacturer's products in New London, Connecticut. Adopting a definition of sale or exchange which requires the tracing of property rights, the Second Circuit held that the transaction did not constitute a sale or exchange.

What the taxpayer gave in return for the cash payment was a release of United's contract obligations, chief of which was its promise not to sell its products to other dealers in New London. Such release not only ended the promisor's previously existing duty but also destroyed the promissee's rights. They were not transferred to the promisor; they merely came to an- end and vanished. ${ }^{73}$

But in a prior case where the material facts were different only in that the agency did not continue on a non-exclusive basis after the termination of the contract (a distinction considered not relevant by the court which decided Starr Bros. ${ }^{74}$ ), the Board of Tax Appeals held the transaction to be a sale. ${ }^{75}$ Employing the same definition as the Starr Bros. court, the Board found that the taxpayer transferred, along with office records and good will; the right to develop and exploit his exclusive territory and thereby to earn royalties. ${ }^{70}$ And the profit qualified for capital gain treatment. The Tenth Circuit reached a result similar to that of the Board of Tax Appeals by employing a different definition of sale and avoiding the necessity of tracing interests. ${ }^{77}$ According to the Tenth Circuit, "Broadly speaking, a sale is a

69. Treas. Regs. $\$ 1.1002-1$ (d) (1957).

70. See Bingham v. Commissioner, 105 F.2d 971 (2d Cir. 1939).

71. Compare Commissioner v. Starr Bros., 204 F.2d 673 (2d Cir. 1953) with Elliott B. Smoak, 43 B.T.A. 907 (1941).

72. 204 F.2d 673 (2d Cir. 1953).

73. Id. at 674 .

74. The court rejected the holding in Jones v. Corbyn, 186 F.2d 450 (10th Cir. 1950), which involved total termination of agency existing under exclusive agency agreement. 204 F.2d at 674.

75. Elliott B. Smoak, 43 B.T.A. 907 (1941).

76. Id. at' 910 .

77. Jones v. Corbyn, 186 F.2d 450 (10th Cir. 1950). 
transfer of property for a valuable consideration."78 After determining that the exclusive insurance agency contract or franchise "had at all times substantial value" and that "acting under its provisions, the agents developed a large and lucrative business,"79 the court had no trouble finding that "by terminating the contract and transferring the business to the company, there was a sale and transfer of a capital asset within the meaning of the statute."80

The paradox of these "sale or exchange" cases is that the existence of a sale or exchange would evidently not have been questioned had the property been transferred to a third party rather than to someone with a pre-existing relationship to the transferred property. $^{81}$ If a right to purchase under a requirements contract or a note were transferred for consideration to a third person, the transaction would undoubtedly qualify as a sale or exchange, although transferring such claims or rights to someone with a pre-existing interest in the underlying property would, under the Starr Bros. reasoning, be some "other disposition." 82 The pre-tax economic impact of a transfer of property appears to be the same whether the transfer is classified as a sale, an exchange, or another disposition. The substantial difference in the tax treatment of the transferor, depending on the relationship of the transferee to the property involved, suggests that the use of "sale or exchange" as a subdivision of "sale or other disposition" has no foundation in the economic realities of the transaction. ${ }^{83}$

\section{The Substitute for Ordinary Income Doctrine}

A more candid effort by the courts to protect the ordinary income component from erosion has been their examination of whether the proceeds from the sale of property represent a "substitute for ordinary income." Such scrutiny was first employed by the Supreme Court in Hort v. Commissioner, ${ }^{84}$ in which the Court was asked to determine the tax status of $\$ 140,000$ paid by a lessee to his lessor for the cancellation of a lease with a fourteen year term remaining. The taxpayer contended that the lump-sum payment should be taxed as capital gain. The Supreme Court, in an opinion by Mr. Justice Murphy, answered:

Where as in this case, the disputed amount was essentially a substitute for rental payments which section 22(2) [now section 61 (a) (5)] ex-

78. Id. at 453 .

79. Id. at 452 .

80. Id. at 453 .

81. See, e.g., Walter H. Sutliff, 46 B.T.A. 446 (1942).

82. See Leh v. Commissioner, 260 F.2d 489 (9th Cir. 1958) (requirements contract); Bingham v. Commissioner, 105 F.2d 971 (2d Cir. 1939) (note).

83. The Third Circuit has expressly disavowed any distinctions based on "the person to whom a ... right is transferred." Commissioner v. Goff, 212 F.2d 875, 876 (3rd Cir. 1954). See also Commissioner v. Ferrer, 304 F.2d 125, 131 (2d Cir. 1962), stating: "[More] recent cases ... have moved away from the distinction ... between a sale to a third person that keeps the 'estate' or 'encumbrance' alive, and a release that results in its extinguishment."

84. 313 U.S. 28 (1941). 
pressly characterizes as gross income, it must be regarded as ordinary income. . . . [This section of the Internal Revenue Code] does not distinguish rental payments and a payment which is clearly a substitute for rental payments. ${ }^{85}$

Does section 61(a) speak to the distinction between ordinary income and capital gain as this statement assumes? Contrary to the intimations of Mr. Justice Murphy in Hort, reference to statutory provision outlining the content of gross income supplies no guides for refining the capital gain ordinary income distinction. The gross income provision applies to ". . . gains derived from dealings in property," 86 a category which would certainly include any "sale or exchange" of property. Since capital gains and losses emanate only from the sale or exchange of property, ${ }^{87}$ section 61 (a) would, under one plausible reading of the Court's statutory interpretation in Hort, totally pre-empt the domain of capital gain.

More fundamentally, any attempt to distinguish between proceeds which substitute for ordinary income and other gains is foredoomed. The market price of investment property is composed of the discounted value of the future income anticipated to flow from the investment while its owner holds it plus the discounted value of the proceeds expected upon the resale of the property at the end of that period. ${ }^{88}$ Upon successive sales the market price continues to be composed of the income and resale constituents, so at any point in time the market price represents anticipated ordinary profits. This proposition is true even for that part of the price which represents the salvage value of the property, for that component represents the profits anticipated by those who will salvage the property. All gain on property transactions could thus be characterized as a substitute for ordinary income. ${ }^{89}$ Presumably, the Court, when it distinguished substituted ordinary income from capital gain, was not referring to so broad an interpretation of substituted income as the preceding statutory and economic analyses provide. But its point of reference remains obscure.

Courts have reacted to the Hort principle in various ways. At least one court has interpreted it as establishing mutually exclusive classes of property rights, one of which gives rise to anticipated ordinary income and, the other, to capital gain. In Bell's Estate $v$. Commissioner, ${ }^{90}$ the Eighth Circuit held that the proceeds from the sale of a life estate in a trust by the life tenant to the remainderman were taxable as capital gain, relying on the Supreme Court's

85. Id. at 31-32.

86. INT. REv. CODE of 1954, § 61 (a) (3).

87. INT. REv. CoDE of 1954, \& 1222.

88. See Samielson, Economics 647-50 (5th ed. 1961); 1 Bonbright, Valuation of Property 216-66 (1st ed. 1937).

89. Compare the effect of $\S 1245$, I*t. REv. Cone of 1954. In this regard, see generally Schapiro, Recapture of Depreciation and Section 1245 of the Internal Revenue Code, 72 Yale L.J. 1483 (1963).

90. 137 F.2d 454 (8th Cir. 1943). 
opinion in Blair $v$. United States. ${ }^{91}$ The Blair case held that the transferee of a life estate was liable for income tax on the annual yield. In the process of distinguishing the Blair facts from earlier cases in which the Court had held that the assignment of income did not transfer tax liability, Chief Justice Hughes found that the owner of a life estate has a beneficial interest in the property. ${ }^{22} \mathrm{He}$ declared, "The assignment of the beneficial interest is not the assignment of a chose in action but of the 'right, title, and estate in and tó property." "'93

The Eighth Circuit equated the Supreme Court's distinction between a transfer of beneficial ownership and an assignment of income to a distinction between proceeds from the sale of a capital asset and proceeds representing a substitute for ordinary income. ${ }^{94}$ But this equation was mistaken. There is no apparent reason why the consideration received for a property interest which, had it been assigned, would have transferred income tax liability, could not be a "substitute for ordinary income" so far as the transferor is concerned. The Eighth Circuit should have recognized that Hort, in concept if not in expression, held that formal satisfaction of the statutory requirements for capital gain did not preclude classifying the transaction's proceeds as a substitute for ordinary income - that is, the finding that a payment represents a substitute for ordinary income does not logically exclude a finding that the transaction involves a sale or exchange of a capital asset. ${ }^{\circ 5}$

Other courts which have used the substitute for ordinary income doctrine to accommodate the competing claims for ordinary income and capital gain taxation have resorted to notions of policy to govern its use. In a case again involving the sale of a life estate, the Second Circuit said the distinction between sale proceeds that were a substitute for ordinary income and those that were capital gain turns on the difference between "anticipation of income payments over a reasonably short period of time and an out-and-out transfer of a substantial and durable property interest, such as a life estate at least is." The Supreme Court in Commissioner v. P.G. Lake, Inc. ${ }^{97}$ appeared to be motivated by two related factors - the near identity between the sale price and the discounted value of the pay out expected from the transferred right (reflecting the lack of economic risk to the transferee) ${ }^{98}$ and the short life

91. 300 U.S. 5 (1937).

92. Id. at $12-13$.

93. Id. at 13-14.

94. Bell's Estate v. Commissioner, 137 F.2d 454, 458 (8th Cir. 1943).

95. The Court assumes that the lessor's rights in the Hort transaction are "property" and says nothing to indicate that the transaction does not qualify as a sale or exchange. The Court seems to be identifying a distinction based on the function of the proceeds rather than the elements of the transaction when it says that proceeds are a substitute for ordinary income. Hort v. Commissioner, 313 U.S. 28 (1941).

96. McAllister v. Commissioner, 157 F.2d 235, 237 (2d Cir. 1946).

97. 356 U.S. 260 (1958).

98. Id. at 265-66. 
of the transferred interest ${ }^{98}-$ when it ruled that the gain on the sale of an oil payment right was taxable as ordinary income. ${ }^{100}$ The factors noted in Lake, however, do not serve to rationalize the cases. The Ninth Circuit, subsequent to Lake, held that a prime-lessee's sale of his remaining leasehold rights of two years' duration to his sub-lessee for a price based on the anticipated rent did not yield a substitute for rental payments because "the transaction constituted a bona fide transfer for a legitimate purpose. . . "101 According to that court, "The case is not one of a liquidation of a right to future income as is Hort, but rather it is one of a disposition of income-producing property itself."102 On the other hand, the Tax Court held prior to Lake that the sale by a taxpayer of his right to receive a fixed percentage of the sales price received by a seller in dealings with a corporation in which the seller and taxpayer were co-owners was an anticipation of ordinary income, although the amount of the periodic payments was unpredictable, the economic life span of the venture was open-ended, and considerable enterprise risk was involved. ${ }^{103}$ Whether or not courts could develop a consistent approach to the substitute-for-ordinary-income doctrine through the use of relevant policy considerations, the structure of the doctrine has not encouraged them to do so, and inconsistencies continue to arise.

\section{The Property Doctrine}

The doctrinal device most recently developed by courts focuses on the definition of capital asset as "property."104 The cases separate into two groups $\rightarrow$ those concerned with the capacity of certain contractual rights to survive a disposition in order to qualify the transaction for capital gain treatment under the strict "sale or exchange" interpretation, and those which deal with the statutory meaning of property.

\section{Naked and Substantial Rights}

The theory that certain property inferests survive a disposition which might otherwise be considered to have extinguished or cancelled them is employed primarily to intróduce exceptions into the framework established by those courts which tend to find the requirements for sale or exchange unsatisfied when contractual rights and duties are terminated. ${ }^{105}$ And this theory suffers from the same flaws of artificiality as its complement, the "sale or exchange" doctrine. ${ }^{106}$ The cases from which this theory descends have little in common with their offspring. The line of cases starts at Blair $v$. United States. ${ }^{107}$. The

99. Id. at 262-63.

100. Id. at 264 .

101. Metropolitan Bldg. Co. v. Commissioner, 282 F.2d 592, 594 (9th Cir. 1960).

102. Ibid.

103. Charles E. McCartney, 12 T.C. 320 (1949).

104. INT. REv. CODE OF 1954, § 1221.

105. See text accompanying notes $68-80$ supra.

106. See text accompanying notes 60-83 sulra.

107. 300 U.S. 5 (1937). 
holding in Blair is that the assignment of a life estate effectively transfers to the assignee the income tax liability on the annual yield. The Supreme Court's decision included a finding that the assignment of a life estate effectively transfers a "right, title, and estate in and to property" to the assignee.108 Although Blair dealt with the income-splitting problem, Bell's Estate v. Commissioner turned that finding into a holding that the assignment of a life estate was the transfer of income producing property rather than merely a transfer of a right to income, and hence gave rise to capital gain. ${ }^{109}$ The Second Circuit, presented with a case involving the sale of a life estate, agreed with the Bell's Estate decision, saying that a life estate was a "substantial and durable property interest."110 As with Bell's Estate, the principal question considered in the Second Circuit's case was whether the sale anticipated future ordinary income.111

The Second Circuit has gradually developed a greater willingness to find the transfer of property requisite for a sale or exchange. ${ }^{112}$ A landmark decision in this development appears in Commissioner v. McCue Bros. \& Drummond, ${ }^{113}$ where the court categorized as the sale of a capital asset a transaction involving a lessor's payment to his lessee on the cancellation of their lease. The court made this inroad on its previously narrow reading of sale or exchange by improvising on the concept of a present property interest introduced in Bell's Estate ${ }^{114}$ to develop a property test, thus distinguishing prior decisions in which it had held that an agent's surrender of his agency contract to the principal did not constitute a sale or exchange:

... [In the agency cases, there was no sale or exchange within the meaning of the statute] because the contractual right was not transferred, but was released and merely vanished. However, we think the right of possession under a lease or otherwise, is a more substantial property right which does not lose its existence when it is transferred.115

Given the court's acceptance of the sale or exchange-sale or other disposition distinction, it is surprising to find the court characterizing the transaction as a transfer rather than an extinction of the lessee's rights; the court offers no explanation for so doing. Yet in this way, the convenient concept of the "more substantial" property right was uncovered. In a later case, the Second Circuit found it expedient to distinguish away $M c C u e$ Bros. in order to resuscitate the rationale of its earlier agency contract cases; it then

108. Id. at 13-14.

109. 137 F.2d 454, 458 (8th Cir. 1943). See also discussion in text at notes $90-94$ supra.

110. McAllister v. Commissioner, 157 F.2d 235, 237 (2d Cir. 1946).

111. Id. at 236.

112. For their rejection of the "sale or exchange" doctrine, see Commissioner $v$. Ferrer, 304 F.2d 125, 131 (2d Cir. 1962).

113. 210 F.2d 752 (2d Cir. 1954).

114. 137 F.2d 454, 457 (8th Cir. 1943).

115. 210 F.2d 752, 753 (2d Cir. 1954). 
discovered the complement of the "more substantial" contract right, the "naked" or "mere contract right."116

Neither the definition of "naked" and "substantial" contract rights nor the difference between them is clear. In both cases, the courts had alternate grounds sufficient to support the decision, ${ }^{117}$ and seem to have used the terms "substantial" and "naked contract rights" only to denote respectively those contract rights which did and did not give rise to capital gain treatment. ${ }^{118}$ It is possible, however, that courts in the future, instead of using the terms only as labels describing the tax consequences reached on other grounds, will reason from the label to the tax treatment. The implications of this possibility are disturbing. In the area of contract rights, for example, the extinguishment principle derived from the sale or exchange doctrine ${ }^{119}$ has limited the availability of capital gain treatment in transactions between parties to a pre-existing contract. If the contract rights so transferred were labeled "naked," then unfavorable tax treatment would also attach where third parties were the transferees of the contract rights. Since the "naked" and "substantial" test provides no foothold in the policies underlying the capital gain statute and, at best, serves only to provide labels for conclusions reached by courts, use of this test will serve to expand the randomness of the sale or exchange doctrine to cover the whole domain of property transactions. In effect, it would abandon what has been an arbitrary method for distinguishing transactions based on the parties involved in favor of an equally arbitrary method of distinguishing transactions based on the "type" of contract rights involved. Classification of the contract rights would be effected by indiscriminate reference to the results of prior judicial sallies into the penumbral area.

Something like this development seems to be reflected in a recent Second Circuit decision. In Commissioner v. Ferrer, ${ }^{120}$ involving a complex transfer of production rights to Moulin Rouge, the court rejected rationalizations previously employed, ${ }^{121}$ in favor of a distinction turning upon whether the rights transferred were enforceable by the transferor at equity. ${ }^{122}$ The court purported to justify the proposed distinction by analyzing situations appearing in prior decisions where capital treatment had been at issue in order to find a distinguishing feature. ${ }^{23}$ Although the former doctrines were abandoned,

116. Commissioner v. Pittston Co., 252 F.2d 344, 348 (2d Cir. 1958).

117. Commissioner v. Pittston Co., 252 F.2d 344 (2d Cir. 1958) (substitute for ordinary income); Commissioner v. McClue Bros. \& Drummond, 210 F.2d 752 (2d Cir. 1954) (sale or exchange).

118. Ibid. See also Leh v. Commissioner, 260 F.2d 489, 493 (9th Cir. 1958).

119. See text accompanying notes 68-73 supra.

120. 304 F.2d 125 (2d Cir. 1962).

121. Id. at 129-31.

122. Id. at 133-34.

123. Id. at 130-31. 
the court's reasoning merely enshrines the arbitrary decisions reached under past doctrines in a new theology.

None of the doctrines examined thus far has provided the courts with a viable basis for determining which transactions give rise to ordinary income and which yield capital gain. As a result confusion marks the body of case law distinguishing between capital gain and ordinary income. Even if courts utilizing the foregoing three doctrines are motivated by relevant policy considerations, the decisions appear couched in ultimate terms that do not lend themselves to reasoned elaboration. This means not that courts using these doctrines cannot reach results generally consistent with the policies underlying the statutory provisions, but that they are unlikely to reach such results. The obligation of a court to reach decisions through reasoning, upon which the coherence of case law depends, is not enforced. Consequently, the ability of courts to learn from one another is diminished, and classification of transactions in this area becomes a function more of accident and less of design. The tax consequences of transactions are sufficiently important to the commercial community ${ }^{124}$ to warrant insistence that courts continue to search for a method of reaching their results through the process of reasoned elaboration. Only through the evolution of a comprehensible pattern of judicial decisions will businessmen be able to predict the tax consequences that will attach to their commercial transactions.

\section{The Business - Investment Distinction}

There is a final line of cases, the second group arising under the "property" requirement, which may provide a sounder doctrinal basis for judicial inquiry than "sale or exchange," "naked and substantial contract right," or "substitute for ordinary income." Beginning with Corn Products Refining Co.v. Commissioner, ${ }^{125}$ these cases, initially through the use of a rough distinction between business property and investment property, attempt to narrow the capital asset concept: by narrowing the range of capital asset they reduce the number of transactions giving rise to capital gain.

Before Corn Products, the "capital asset" concept was not seen as a fruitful source of limitations on capital gain treatment. Lower courts normally either assumed that the asset involved in the transaction before them was a capital asset or read what is now section 1221 with the following syllogistic reasoning, to reach the same result:

a) "capital asset" means property as defined by the general body of property law, except for that property within the five specified excluded classes.

b) the right under consideration is considered property within the body of general law and does not fit within any of the statutory exclusions.

c) therefore, the property right is a capital asset. ${ }^{126}$

124. See Commissioner v. Pittston Co., 252 F.2d 344, 352 (2d Cir. 1958) (dissenting opinion).

125. 350 U.S. 46 (1955).

126. Jones v. Corbyn, 186 F.2d 450 (10th Cir. 1950). 
In Hort v. Commissioner, ${ }^{127}$ the Supreme Court began to undermine the syllogism by attacking the first part of the major premise. In holding that a payment from a lessee to a lessor in return for the cancellation of a lease was ordinary income because the payment was a substitute for rental income, the Court said, "[I]t is immaterial that for some purposes the contract creating the right to such payments may be treated as 'property' or 'capital.' "128 It was this hint that the Court in Corn Products picked up and developed into an explicit rejection of the proposition that property is used in its ordinary sense within the definition of capital asset in section 1221 .

The Corn Products Company, because it had limited storage facilities, bought corn futures during the harvest season to avoid the effects of a price rise if one should occur during the year. It would then either take delivery during the year, or sell the futures and with the proceeds buy corn in the spot market as it was needed. ${ }^{129}$ The company claimed that the gains arising on the sales of futures were capital gains. The Supreme Court disagreed:

[The petitioner's transactions] do not come within the literal language of the exclusions. . . . They were not stock in trade, actual inventory, property held for sale to customers or depreciable property used in a trade or business. But the capital asset provisions of section 117 [now section 1221] must not be so broadly applied as to defeat rather than further the purpose of Congress. . . . Congress intended that profits and losses arising from the everyday operation of a business be considered as ordinary income or loss rather than capital gain or loss. The preferential treatment ... applies to transactions in property which are not the normal source of business income. ${ }^{130}$

Notice how the Court proceeded in Corn Products. It admitted that it could not fit the taxpayer's transaction within the stock in trade, actual inventory, or other section 1221 exclusions ; but it used those categories as indicia, pointing toward the type of property Congress intended to exclude. It capsulized this intent by distinguishing between those transactions which arise from the "everyday operation of a business"131 and those which arise from the activities of a "legitimate capitalist."132 Applying this distinction to the facts in the case, the Court said:

[T] The claim of Corn Products that it was dealing in the market as a "legitimate capitalist" lacks support in the record. ... [I]n labeling its activity as that of a "legitimate capitalist" exercising "good judgment" in the futures market, petitioner ignores the testimony of its own officers that in entering that market the company was "trying to protect a part of [its] manufacturing costs"; that its entry was not for the purpose of "speculating and buying and selling corn futures" but to fill an actual "need for the quantity of corn [bought] ... in order to cover ... . what

127. 313 U.S. 28 (1941).

128. Id. at 31 .

129. 350 U.S. $46,48-49$ (1955).

130. Id. at 51-52.

131. Id. at 52 .

132. Id. at 50 . 
[products] we expected to market over a period of fifteen or eighteen months." It matters not whether the label be that of "legitimate capitalist" or "speculator"; this is not the talk of the capital investor but of the farsighted manufacturer. For tax purposes petitioner's purchases have been found to "constitute an integral part of its manufacturing business." ...133

Rights and assets involved in the daily ebb and flow of business activity would, if sold, give forth ordinary income. Thus, if a company contracted to purchase raw materials one year hence but sold the right to receive the material shortly before the shipment was due, the proceeds of the transaction would seem to be taxable at ordinary rates. With an "everyday operation" test as a crucial determinant of the taxation of transactions, the use made of the property by the taxpayer rather than its external characteristics becomes the critical factor. Distinguishing according to the role an asset plays in commercial enterprises leads to the business property-investment property distinction which emerges from the Corn Products opinion. ${ }^{134}$

The distinction between business property and investment property might, like the other doctrinal distinctions, appear to be simply a restatement of the capital gain-ordinary income dichotomy, offering as little direction and as little hope for reasoned elaboration. As a starting point for judicial decisions, however, the business-investment distinction may have an advantage. The doctrinal tests of "sale or exchange," "substitute for ordinary income" and "naked or substantial" contract rights were established and continue to exist primarily within the confines of the taxation statute and case law. Constructed for use in the area of capital gain taxation, these concepts, to the extent they are sensible, have no intrinsic content but rather provide frameworks for the expression of decisions reached by other means. In his search for meaning, the decision-maker is inexorably drawn back into the vortex of policies underlying the statute; but, without a suitable reference point, the complex and confusing policy considerations do not provide a satisfactory basis for judicial reasoning. Analysis of the policies and transactions on a case-to-case basis demands more expertise and sophistication in economics than courts should be asked to provide. Unlike the concepts employed in the other doctrinal distinctions, "business" and "investment" have some reference to real world experience. Although "business" and "investment" would require further elaboration before providing a workable standard, they offer at least the possibility that an examination of differences between them will suggest some external distinction which will appear relevant to the differing tax treatment.

\section{The Capital Structure Test}

The Supreme Court has had one opportunity to elaborate the business property-investment property distinction, in Commissioner $v$. Gillette

133. Id. at 50-51.

134. See generally, Surrey, Definitional Problems in Capital Gains Taxation, 69 HARV. L. REv. 985 (1956). 
Motor Transport, Inc. ${ }^{135}$ but passed it by. The experience of Corn Products in the Fifth Circuit offers more promise. A recent decision there seems to provide an important advance in the elaboration of the distinction. Nelson Weaver Realty Co. v. Commissioner ${ }^{136}$ concerned the sale of the taxpayer's rights as mortgage servicing agent under an agreement with a major insurance company. Distinguishing the Corn Products facts, the court said:

By no stretch of the imagination can the routine day-to-day sale of corn futures be equated with an isolated sale of an agency contract. Here the taxpayer sold and transferred a franchise or contract which for eight years had constituted one of the chief items of its capital structure. . . This was one isolated transaction in which the taxpayer disposed of property which was the means by which it had conducted more than half of its business operations over a period of years. ${ }^{137}$

The concept of a "chief item in an enterprise capital structure" is, in a sense, only one step removed from "investment," but the step is in the direction of clarification. The "profits and losses arising from the everyday operation of a business" of Corn Products is contraposed to the gain on the sale of a major item in an enterprise capital structure. The distinction which emerges in Nelson Weaver is between property which is introduced into the enterprise's business activities, is processed, and either exits as part of the final product or is consumed in its production and property which enables the enterprise to process its raw materials. ${ }^{138}$

This distinction, of course, has its difficult points. Just as every transaction involves a substitute for ordinary income, so most assets, including many given capital treatment as a matter of course, ${ }^{139}$ are devoted to the production process and eventually consumed in it. Because there exists a referent to experience in the real world, however, a meaningful line may emerge. One means of approaching the problem would be to analyze those assets traditionally considered part of the capital structure and to contrast them with assets not considered part of that structure. The buildings within which an enterprise operates, as well as the land they occupy and the machinery employed inside them, are normally assumed to fall in the capital structure category. One characteristic such assets have in common is the length of time they contribute to the enterprise operation. Such assets produce a stream of income. On the other hand, raw materials and inventory property, both of which are con-

135. 364 U.S. 130 (1960). The case is discussed in the text at notes 53-54 supra.

136. 307 F.2d 897 (5th Cir. 1962).

137. Id. at 902 .

138. The viability of the Weaver decision is already in question. Within three months of its publication, Weaver was limited by a different Fifth Circuit panel to situations involving "a sale of a property right equivalent to a sale of a business and good will. ..." United States v. Eidson, 310 F.2d 111, 116 (5th Cir. 1962). More recently, however, a third panel of the Fifth Circuit has rejected Eidson and attempted to resuscitate Weaver. United States v. Dresser Industries, Inc., 12 Am. Fed. Tax R.2d 5892 (5th Cir. 1963).

139. See, e.g., Aaron Michaels, 12 T.C. 17 (1949). 
sidered outside the capital structure, make only a one-shot contribution to enterprise income.

This duration phenomenon is not only characteristic of assets traditionally considered part of the capital structure but also is characteristic of assets which, in well-settled areas, give rise to capital gain tax treatment. Good will provides an excellent example. ${ }^{140}$ Good will represents the difference between the enterprise's value as a going concern and its physical value. ${ }^{141}$ Good will is embodied in such advantages as business locations, a trained staff, special processes, and an established clientele, all of which present additional moneymaking opportunities to the enterprise possessing them. ${ }^{142}$ These opportunities usually present themselves over a long period. If good will is sold, the opportunity for future income is cashed in, and capital gain treatment is accorded. ${ }^{143}$ The treatment of section 1231 assets offers another illustration. ${ }^{144}$ That section provides that real property and depreciable property used in trade or business, machinery for example, are to receive capital gain treatment under prescribed, but not unusual, circumstances. ${ }^{145}$ This property also has the potential for making a continuing contribution to enterprise income. In contrast, those assets specifically excluded from the capital asset treatment are, by and large, only fleetingly involved in the productive operation of an enterprise. ${ }^{146}$

The existence or non-existence of the potential for making a continuing contribution to the enterprise seems a potentially valuable test for identifying items in the capital structure, since it evidently coincides with a characteristic distinguishing property which gives rise to capital gain from property which does not. For non-business situations, the same potential for continuing contributions to income - imputed or actual - bears equal promise. The question remains, however, whether such a test, based on the potential duration of an asset's contribution to the enterprise, identifies a fortuitous distinction between capital gain and ordinary income transactions or, in fact, reflects to a significant extent the policies said to underlie the capital gain provisions. ${ }^{\mathbf{1 4 7}}$ When disposition of the property would collapse the anticipated stream of

140. Id. at 19.

141. George J. Staab, 20 T.C. 834,840 (1953).

142. See Bittker, Capital Gains and Losses 72-73 (unpublished materials in Yale Law Library, 1963).

143. See, e.g., Aaron Michaels, 12 T.C. 17, 19 (1949).

144. See, e.g., Victory Housing No. 2, Inc. v. Commissioner, 205 F.2d 371 (10th Cir. 1953).

145. See Bittker. Federal Income, Estate and Gift Taxation 403-07 (2d ed. 1958).

146. INT. Rev. CoDE of 1954, § 1221(1) and (3).

147. See, by way of comparison, Commissioner v. Ferrer, 304 F.2d 125 (2d Cir. 1962), discussed in text at notes 120-23 supra, in which the court analyzes results and finds that contract rights give rise upon sale to capital gain or ordinary income depending upon whether the interest of the vendor is enforceable in equity. 304 F.2d at 130-34. See generally, Robinson, Definition 96-98, 170-89 (1954) (discussing definition by analysis). 
income into a single amount, the telescoping policy would apply. ${ }^{148}$ Property which produces a stream of income - both real investment property which contributes directly to economic growth and financial investments which enable real investment to take place - is the object of the investment encouragement policy. ${ }^{149}$ The policy of keeping investment funds liquid in order to accelerate revenue production is particularly applicable to income which can be realized either presently or over a period of years. ${ }^{150}$ And long run inefficiency in the market allocation of resources has a harsher effect on the economy than short term inefficiency. ${ }^{151}$

The utility of the stream of income test for the determination of proper tax treatment can be seen by applying it to some of the transactions which have generated litigation testing the capital gain-ordinary income distinction. Suppose the taxpayer has a favorable requirements contract for the supply of coal for, say, a 30 year period. That contract is like a machine or good will, providing the taxpayer with a continuing stream of income. Consequently, under the Weaver guide its sale gives rise to proceeds taxable at capital gain rates. ${ }^{152}$ In terms derived from Corn Products, the profits on the sale of such a right constitute investment, not business, income. Of course, if the requirements contract were to supply the enterprise for a term of days or months, its character as an element in the capital structure would disappear. The short-term requirements contract contributes to the stream of income for too brief a duration to be considered an investment. It seems more like the property in the exclusionary categories, such as inventory and accounts receivable. ${ }^{153}$ Similarly, the treatment of payments to a lessee ${ }^{154}$ or a lessor ${ }^{155}$ in consideration for cancellation of a lease would depend upon the productive life of the property given up. The transfer of a fifteen year lease might well be treated in a different manner from the sale of a two year leasehold interest.

If "stream of income" is the test to determine inclusion in the capital structure and claims to capital gain treatment, courts will be confronted with the problem of setting minimum limits before the source of an income stream will be recognized as a capital asset. A means for meeting this uncertainty is suggested by the Clifford solution to the income-splitting controversy. ${ }^{156}$ The Supreme Court held in Helvering $v$. Clifford ${ }^{157}$ that trust income was

148. See text accompanying notes 34-42 supra.

149. Sec text accompanying note 46 supra.

150. See text accompanying notes 48-50 supra.

151. See text following note 50 supra.

152. But see Leh v. Commissioner, 260 F.2d 489 (9th Cir. 1958), and Commissioner v. Pittston Co., 252 F.2d 344 (2d Cir. 1958).

153. Int. Rev. Cone of 1954, § 1221(1), (3), (4), and (5).

154. See, c.g., Commissioner v. Golonsky, 200 F.2d 72 (3rd Cir. 1952).

155. But see Hort v. Commissioner, 313 U.S. 28 (1941).

156. The case for administrative activitism is well made in Eisenstein, Sone Iconoclastic Reflections on Tax Administration, 58 HARv. L. Rev. 477 (1945).

157. 309 U.S. 331 (1940). 
taxable to whomever had substantial ownership of the trust property. But the guides for judicially determining "substantial ownership" were so troublesome that one-hundred and fifty cases and a confusing body of case law was generated in the five years following the Clifford decision. ${ }^{158}$ At that point, the Treasury came to the rescue with the now famous Clifford Regulations, ${ }^{160}$ presently incorporated in the Internal Revenue Code. ${ }^{160}$ The Clifford Regulations stated that if the settlor surrendered control of trust income and corpus for at least ten years the income from the trust would be taxed to the trust beneficiary and not to the settlor. In some sense the Treasury decision was arbitrary, ${ }^{161}$ but it was founded in experimentation and at least provided a bright-line standard. ${ }^{162}$ Predictability, after all, should be a touchstone of tax administration. The penumbral area of the capital gain-ordinary income distinction seems to be an area which would also benefit from Clifford treatment.

If property qualifying for capital asset classification is limited to capital structure property, judges and administrators might well consider an attempt to co-ordinate their notions of a qualified transaction to the requirements imposed on "capital asset property." Both the telescoping ${ }^{163}$ and investment liquidity ${ }^{164}$ policies presume an accelerated realization of anticipated earnings. Courts and administrative departments therefore might reasonably require not only that an asset representing a stream of income be converted, but also that in order to qualify for capital gain treatment the stream of income be converted into either a lump-sum payment or a series of payments to be realized during a period substantially shorter than the stream was expected to run. ${ }^{165}$

158. Eisenstein, Some Iconoclastic Reflections on Tax Administration, 58 HARv. L. REv. 477, 492 (1945).

159. T.D. 5488, 1946-1 CuM. Burt. 19.

160. INT. REv. Code of 1954, \$§ 671-78.

161. See Commissioner v. Clark, 202 F.2d 94 (7th Cir. 1953), in which the court maintains that the conclusive presumption of the Clifford Regulations is "arbitrary" to the extent of being unconstitutional. The Internal Revenue Service announced that it did not intend to follow the principle announced in Clark, Rev. Rul. 54-48, 1954-1 Cum. BuLL. 24, and the Clifford statutory provisions have not been declared unconstitutional.

162. See Eisenstein, The Clifford Regulations and the Heavenly City of Legislative Intention, 2 TAX L. REv. 327 (1946), and Some Iconoclastic Reflections on Tax Administration, 58 HARV. L. REv. 477 (1945).

163. See text at notes $34-45$ supra.

164. See text at notes 47-50 supra.

165. This requirement could be imposed through defining the phrase sale or exchange as it is used in the capital gain sections. An obvious precedent is the process of defining property initiated in Corn Products, discussed at notes 125-38 supra. 